\begin{abstract}
Iranica
Abstracta Iranica Revue bibliographique pour le domaine irano-aryen

Volume 40-41 | 2019

Comptes rendus des publications de 2017-2018
\end{abstract}

\title{
Josette Elayi. « Tyr et Sidon, deux cités phéniciennes rivales»
}

\section{Astrid Nunn}

\section{(2) OpenEdition}

1 Journals

\section{Édition électronique}

URL : http://journals.openedition.org/abstractairanica/48398

DOI : 10.4000/abstractairanica.48398

ISBN : 1961-960X

ISSN : 1961-960X

Éditeur :

CNRS (UMR 7528 Mondes iraniens et indiens), Éditions de l'IFRI

\section{Référence électronique}

Astrid Nunn, « Josette Elayi. «Tyr et Sidon, deux cités phéniciennes rivales » », Abstracta Iranica [En ligne], Volume 40-41 | 2019, document 35, mis en ligne le 15 juillet 2019, consulté le 16 avril 2021. URL : http://journals.openedition.org/abstractairanica/48398; DOI : https://doi.org/10.4000/ abstractairanica.48398

Ce document a été généré automatiquement le 16 avril 2021

Tous droits réservés 


\title{
Josette Elayi. « Tyr et Sidon, deux cités phéniciennes rivales »
}

\author{
Astrid Nunn
}

\section{RÉFÉRENCE}

Josette Elayi. « Tyr et Sidon, deux cités phéniciennes rivales », Transeuphratène 49, 2017, p. 91-101

1 Déjà Strabon écrivait que Tyr et Sidon rivalisaient. Ces deux cités ne sont éloignées que de $35 \mathrm{~km}$. Elles étaient toutes deux ambitieuses et expansionnistes. L'A. analyse comment ces deux cités se voyaient en rivales sur leur ancienneté et les traditions souvent divergentes de leur puissance. Sur le plan politique, leur rivalité commença à se manifester sous Xerxès I. Celui-ci semble au cours de la deuxième guerre médique avoir plus loué la flotte tyrienne, mais en revanche plus sollicité la flotte sidonienne qui, en conséquence, subit des pertes plus lourdes. Tyr, puis peu après Sidon, ont émis des monnaies. Après une longue période de richesse pour Sidon, Tyr redeviendra la première cité phénicienne vers 350 av. J.-C.

\section{AUTEURS}

\section{ASTRID NUNN}

Université de Munich 